\title{
Older patients with intraventricular hemorrhage are prone to infection after external ventricular drainage
}

\author{
(1) Soner Yaşar, M.D., (ㄱ) Alparslan Kırık, M.D.
}

Department of Neurosurgery, University of Health Sciences Gülhane Training and Research Hospital, Ankara-Turkey

\begin{abstract}
BACKGROUND: External ventricular drainage (EVD) is a life-saving and emergent procedure in neurosurgery. However, infection is the main problem in patients with EVD. The present study aims to analyze the infection rate of patients with EVD and to investigate the factors that contribute to infection and mortality rates.

METHODS: The data of patients who underwent emergent EVD procedure between 2018 and 2019 were retrospectively analyzed in this study. The demographic features of the patients were recorded. The correlation between age, gender, indication and duration of EVD, and the infection and mortality rate were investigated.

RESULTS: In this study, 47 patients underwent emergent EVD in two years. Thirty $(63.83 \%)$ patients were male, and 17 were female with a mean age of 28.02 years. The mean duration of drainage was 6.2 days. Fifty-eight cerebrospinal fluid (CSF) samples were analyzed during the drainage period and CSF culture was positive in 14 (24.14\%) samples. The most common microorganism was Staphylococcus epidermidis. The infection rate was high in older and male patients with duration longer than six days. Nine (19.15\%) patients died during the treatment period and six of them had IVH.
\end{abstract}

CONCLUSION: The duration of EVD should be shorter in patients older than 65 years with the diagnosis of intraventricular hemorrhage, which is mostly related to death.

Keywords: Cerebrospinal fluid; external ventricular drainage; mortality; neurosurgery.

\section{INTRODUCTION}

External ventricular drainage (EVD) systems are devices placed in cases of acute hydrocephalus or intraventricular hemorrhage to monitor intracranial pressure (ICP) and to drain the cerebrospinal fluid (CSF) or blood within the ventricle. ${ }^{\left[{ }^{[}\right]}$It is a basic and simple but emergent treatment method in patients with increased ICP which is a life-threatening condition. ${ }^{[1,2]}$ Moreover, it plays a therapeutic role by allowing drainage of CSF or intraventricular blood. However, the main disadvantage of EVD is the risk of infection (ventriculitis or meningitis) arises due to this procedure. In the literature, the risk of infection has been reported between $0-45 \% .^{[2-4]}$ The infection secondary to EVD may lead to significant morbidity or mortality if not it is managed properly. ${ }^{[5,6]}$
Today, the diagnostic criteria of infection are significant for treatment. The strongest diagnostic criterion is the CSF culture, which is obtained during the drainage. Another reliable diagnostic method is cell count within the CSF. The decrease in CSF glucose level and the increase in protein level are less reliable than the CSF culture or cell count, but should also be measured in the CSF. ${ }^{[6,7]}$ However, it is not well documented the factors that contribute the infection rates in patients with EVD.

Duration of EVD, primary disease-causing increased ICP, concomitant infection, type of surgical intervention, CSF fistula are defined as risk factors for infection during EVD. ${ }^{[6-9]}$ Many factors have also been investigated previously to reduce the infection rate during the EVD. However, discussions on differ-

Cite this article as: Yaşar S, Kırık A. Older patients with intraventricular hemorrhage are prone to infection after external ventricular drainage. Ulus Travma Acil Cerrahi Derg 2020;26:870-874.

Address for correspondence: Soner Yaşar, M.D.

SBÜ Gülhane Eğitim ve Araştırma Hastanesi, Beyin ve Sinir Cerrahisi Kliniği, Ankara, Turkey

Tel: +90 312 - 3045344 E-mail: dr.soneryasar@gmail.com

Ulus Travma Acil Cerrahi Derg 2020;26(6):870-874 DOI: 10.14744/tjtes.2020.06I59 Submitted: 19.06.2020 Accepted: 16.07.2020 Online: 21.10.2020

Copyright 2020 Turkish Association of Trauma and Emergency Surgery 
ent variables still continue. The duration of EVD is a matter of debate on ventriculostomy-related infections. ${ }^{[8-10]}$

In our study, the data of patients who underwent emergent EVD in the department of neurosurgery between 2018-2019 were examined retrospectively. Different factors were analyzed to investigate the infection and mortality rates in patients with EVD.

\section{MATERIALS AND METHODS}

The ethical approval of this retrospective study was obtained from our institution. In this study, 47 patients underwent EVD (Argifix ${ }^{\circledR}$, ArgiGroup, Ankara, Turkey) in the Department of Neurosurgery between January 2018 and December 2019 (Fig. I).

\section{EVD Technique}

The patient was laid on the bed with slight head elevation in the supine position. Hair was removed, and the scalp was prepared in a sterile fashion. After installation of local anesthesia, a burr hole was placed at Kocher's point or Frazier's point based on the ventricular anatomy of the patient. The dura was coagulated and opened. Then, the ventricular catheter was inserted, aiming in a coronal plane toward the medial canthus of the ipsilateral eye and in the anteroposterior plane toward a point $1.5 \mathrm{~cm}$ anterior to the ipsilateral tragus, toward the ipsilateral Foramen of Monro. In cases of intraventricular hemorrhage, endoscopic ventricle irrigation was performed and the ventricle catheter was inserted under endoscopic visualization (Fig. 2). The length of the catheter was determined based on the anatomy and size of ventricles. Once the CSF flow was visualized, the catheter was fixed with suture. Then, it was tunneled through the skin away from the point of entry and connected to the drainage bag or reservoir.

Periodical CSF samples were obtained from the reservoir for biochemical and microbiological analysis. CSF culture is a routine procedure in our department in patients with EVD.

The data of patients were collected and analyzed. Age, gender, diagnosis, duration of EVD, CSF glucose and protein levels, results of CSF culture and the outcomes of the patients were retrospectively examined.

SPSS 19.0 software was used for statistical analysis (SPSS Inc., Chicago, IL). Descriptive statistics, Spearman correlation and chi-square test were used for the analysis of the data. A $p$ value $\leq 0.05$ was accepted as an indicator of significance in all comparisons.

\section{RESULTS}

A total of 47 patients underwent EVD over two years. Thirty $(63.83 \%)$ patients were male and 17 were female with a mean age of 28.02 years (ranged between 0 and 88 years).
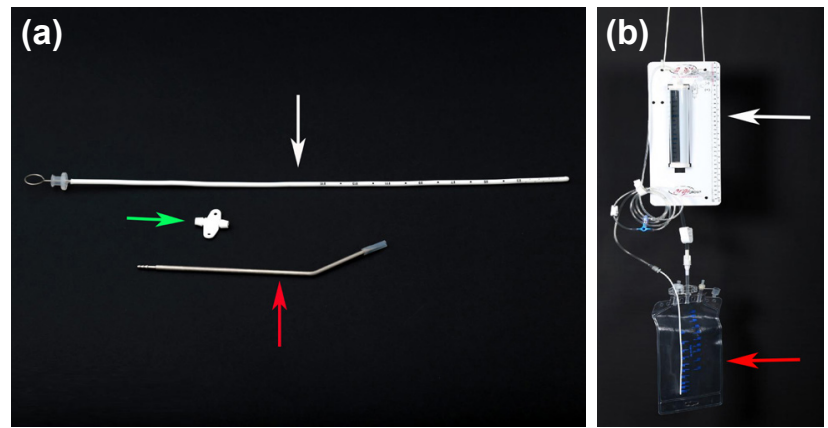

Figure 1. Picture of an external ventricular drainage system. (a) Ventricular catheter (white arrow), small silicone fixation tab (yellow arrow) and trocar needle (red arrow) to allow catheter passage under the skin. (b) Drip chamber (white arrow) and collection bag (red arrow).

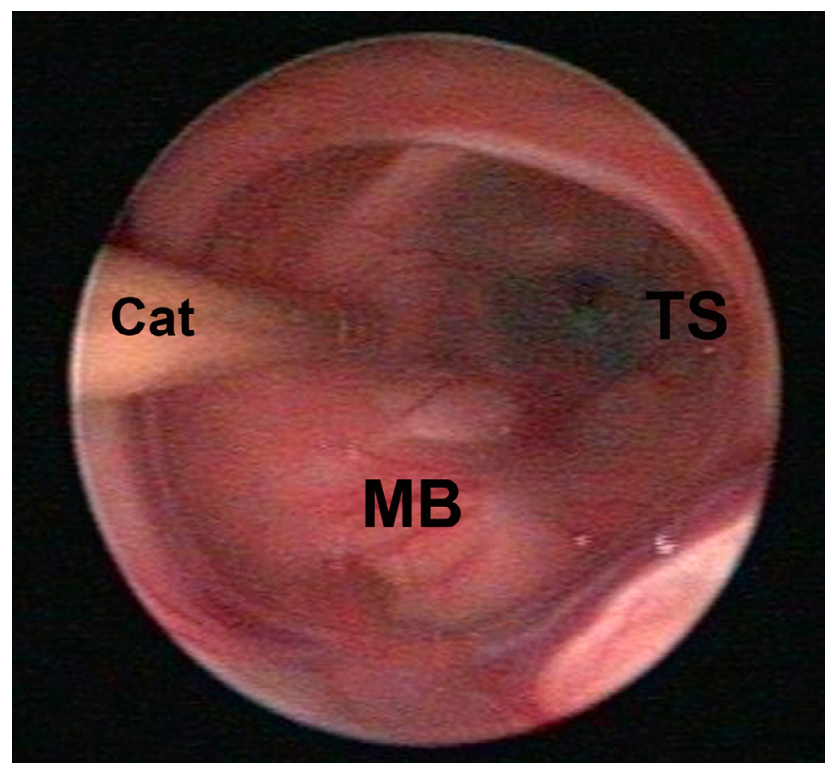

Figure 2. Endoscopic view of EVD catheter within the ventricle (MB: Mamillary bodies, TS: Tuber cinereum, Cat: Catheter).

The mean duration of drainage was 6.2 days, ranged between three and nine days. The diagnosis of patients were hydrocephalus $(n=22)$ (Fig. 3a), intraventricular hemorrhage (IVH) $(n=13)$ (Fig. 3b), intraventricular tumor $(n=7)$ (Fig. 3c), posterior fossa tumors $(n=4)$ and traumatic brain injury $(n=I)$ (Table I). Fifty-eight CSF samples were obtained from 47 patients. CSF culture was positive in 14 (24.14\%) of 58 samples. Staphylococcus epidermidis $(n=4)$, Enterococcus faecium $(n=2)$, Klebsiella pneumoniae $(n=2)$, Staphylococcus haemolyticus $(n=2)$, Acinetobacter baumannii $(n=2)$, Staphylococcus hominis $(n=l)$ and Mycobacterium spp $(n=I)$ were identified in the culture of $58 \mathrm{CSF}$ samples. The mean CSF glucose was $29.78 \mathrm{mg} / \mathrm{dl}$ (ranged between I and $63.3 \mathrm{mg} / \mathrm{dl}$ ) and the mean CSF protein level was $428.3 \mathrm{I} \mathrm{mg} / \mathrm{dl}$ (ranged between 134 and $707 \mathrm{mg} / \mathrm{dl}$ ) in patients with positive CSF culture. Infection was more common in male patients, but this is not statistically significant $(p>0.05)$. The duration of EVD is statistically significantly correlated with the infection rate $(p<0.05)$. In addition, the infection was more frequent in patients older than 

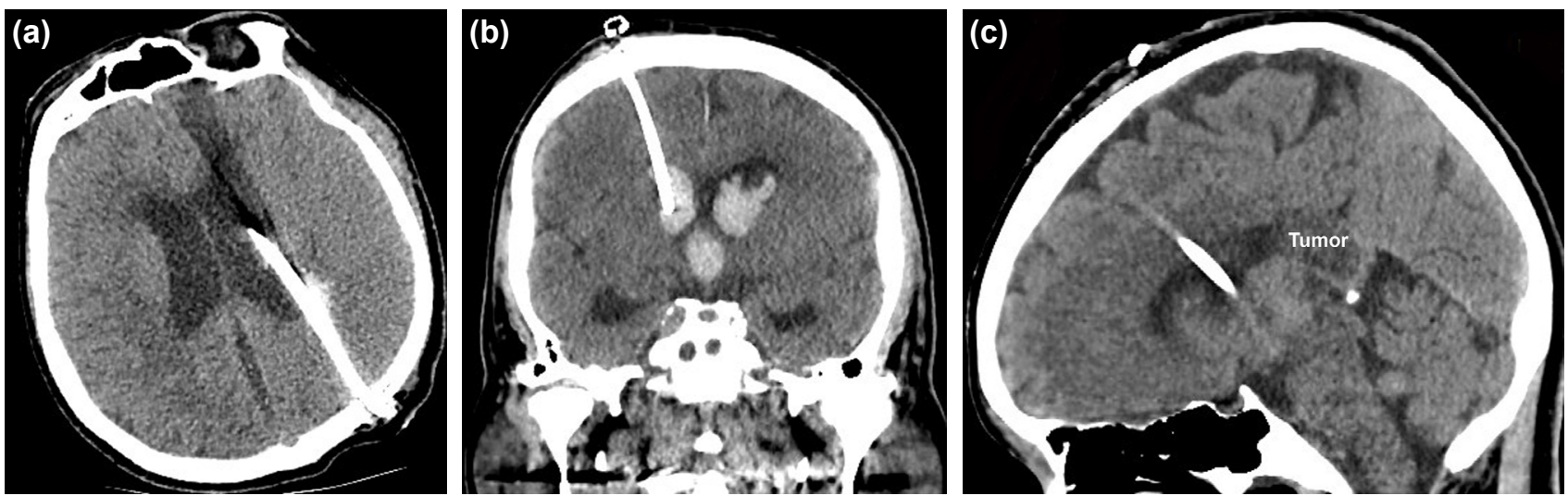

Figure 3. (a) Axial CT scan of a 60-years old male patient with hydrocephalus. The catheter was inserted through Frazier's point. (b) Coronal CT scan of a 64-years old male patient with intraventricular hemorrhage. The EVD catheter is passing through the brain tissue and reaching to the lateral ventricle. (c) Sagittal CT scan of a 32-years old female patient with an intraventricular tumor. The EVD catheter was in the lateral ventricle in front of the tumor.

65 years old and this is also statistically significant $(p<0.05)$. Nine (19.15\%) of 47 patients died during the follow-up period. Among them, microorganism (Mycobacterium spp) was isolated in only one patient and the pre-EVD diagnosis was $\mathrm{IVH}$ in six patients. Univariate regression analysis demonstrated that the risk of infection is significantly increased in patients older than 65 years old $(p<0.05)$.

\section{DISCUSSION}

EVD is a basic and simple method of treatment in patients with increased ICP. EVD is performed in medical practice since the second half of the $18^{\text {th }}$ century. It is also used to drain blood or infected CSF in patients with IVH or infection. The main disadvantage of EVD is the risk of life-threatening ventriculitis or meningitis due to this application. Champey et al. ${ }^{[9]}$ performed a retrospective study in 462 patients with EVD and they suggested an EVD care bundle, which can include routine daily CSF sampling, for prevention of EVD-related infection. Sam et al. ${ }^{[10]}$ reported an infection rate of 6.3\% in 796 patients with EVD and they found that Acinetobacter baumannii was the most common organism causing ventriculostomy-related infection. In our series, CSF infection was detected in 14 of 47 patients and one of them died after the treatment in whom the diagnosis was intraventricular hemorrhage. Staphylococcus epidermidis was mostly isolated microorganism in our series. The CSF glucose level should be $40-80 \mathrm{mg} / \mathrm{dl}$ and the CSF protein level should be $15-60$ $\mathrm{mg} / \mathrm{dl}$ in normal healthy individuals. However, in our series, the mean CSF glucose level was $29.78 \mathrm{mg} / \mathrm{dl}$ and the mean CSF protein level was $428.31 \mathrm{mg} / \mathrm{dl}$ among patients with CSF infection. The CSF protein level was significantly high in patients with infection and the glucose level was below the normal CSF glucose level.

Hydrocephalus is the most common indication of EVD. Hydrocephalus may develop due to intracranial tumors or hemorrhages by blocking the CSF pathways or impairing CSF absorption ${ }^{[11-13]}$ This increases ICP and poses a life-threatening condition to the patient. EVD placement is an emergent but life-saving procedure in hydrocephalus patients whose clinical condition is rapidly deteriorating and unconscious, ${ }^{[14]}$ especially in hydrocephalus patients with shunt dysfunction, this procedure decreases rapidly the ICP and prevent the brain herniation. Emergent EVD is also placed in intraventricular hemorrhages $(\mathrm{IVH})$ that have occurred for different reasons besides hydrocephalus. Subarachnoid hemorrhages are the main causes of IVH, followed by intraventricular tumors or ventricular injuries secondary to severe head traumas. Emergent evacuation of the intraventricular blood is required by the placement of EVD. Song et al. ${ }^{\left[{ }^{[I]}\right]}$ compared the EVD and

Table I. The demographic features and laboratory results of 47 patients who underwent EVD

\begin{tabular}{|c|c|c|c|c|c|c|c|}
\hline Indication of EVD & $\begin{array}{c}\text { Number } \\
\text { of patients }\end{array}$ & $\begin{array}{c}\text { Mean age } \\
\text { (years) }\end{array}$ & $\begin{array}{l}\text { Male/ } \\
\text { Female }\end{array}$ & $\begin{array}{c}\text { Mean CSF } \\
\text { glucose }(\mathrm{mg} / \mathrm{dL})\end{array}$ & $\begin{array}{c}\text { Mean CSF } \\
\text { protein }(\mathrm{mg} / \mathrm{dL})\end{array}$ & $\begin{array}{l}\text { Positive } \\
\text { CSF culture }\end{array}$ & Death \\
\hline Hydrocephalus & 22 & 5 & $14 / 8$ & 12.35 & 524.6 & 13 & 1 \\
\hline Intraventricular hemorrhage & 13 & 65.75 & $9 / 4$ & 40.24 & 367.43 & I & 6 \\
\hline Intraventricular tumor & 7 & 42.26 & $3 / 4$ & 45.56 & 100.8 & 0 & 2 \\
\hline Posterior fossa tumor & 4 & 34.43 & $3 / 1$ & 70.12 & 66.58 & 0 & 0 \\
\hline Traumatic brain injury & 1 & 23 & $\mathrm{I} / 0$ & 54.9 & 147.7 & 0 & 0 \\
\hline
\end{tabular}

CSF: Cerebrospinal fluid; EVD: External ventricular drainage. 
endoscopic evacuation in patients with IVH and they found that endoscopic hematoma evacuation has an advantage of a higher hematoma clearance rate, fewer complications and better outcomes in severe IVH. Basaldella et al. ${ }^{[15]}$ pointed out that endoscopic blood aspiration reduces shunt dependency in patients with IVH. In our series, I3 (27.66\%) of 47 patients underwent EVD for IVH and six (66.66\%) of them died despite the treatment. The mean age of these patients was 65.75 years and all of them had associated co-morbidities. Our findings revealed that patients older than 65 years were more prone to infection when compared with younger patients. In addition, the infection was more common in male patients, but this was not statistically significant.

EVD is also widely used to lower ICP after traumatic brain injuries (TBI). ${ }^{[16]}$ Craniocerebral gunshot wounds may increase ICP and conventional methods fail to treat intracranial hypertension. ${ }^{[16-19]}$ In those times, emergent EVD may be a life-saving procedure for the patient. Bhargava et al. ${ }^{[20]}$ reported their study on the efficacy of EVD on the management of increased ICP in I 39 patients with TBI refractory to conventional medical treatment. EVD was inserted in 16 patients and they found that patients treated with EVD had a lower risk of needing definitive treatment for ICP control. Chau et al. ${ }^{[21]}$ emphasized the significance of EVD in the management of TBI. They suggested that this procedure can improve brain perfusion and mitigate the risk of exacerbating the secondary cerebral injury, as well as reduce the probability of brain herniation in TBI patients. In our series, one of the 47 patients had a traumatic brain injury and underwent EVD for seven days. This patient was discharged after a successful treatment period.

Silicone catheters are generally used in EVD systems and it is claimed that bacterial colonization is less in these catheters. ${ }^{[22]}$ However, it has been suggested that polyurethane catheters can also be used for CSF drainage. ${ }^{[23]}$ We should note that antibiotics or silver-impregnated catheters have also been shown to be effective in preventing infection. ${ }^{[23-26]}$ Meanwhile, Nilsson et al. ${ }^{[27]}$ reported that silver-coated EVD cannot reduce the use of antibiotics or provide shorter hospital stay in cases of ventriculitis. Studies on the development of EVD catheters are still ongoing. In our series, we used silicone catheters in all patients and not used any antibiotic or silver-impregnated catheter. However, our infection rate was compatible with the series of antimicrobial catheters. This is probably due to the lost antimicrobial features of catheters after a short period following EVD insertion.

The limitations of our study are the retrospective nature and low patient population.

\section{Conclusion}

The duration of EVD should be shorter than six days in patients older than 65 years to prevent the infection. IVH is related to high mortality. More clinical studies in larger popula- tions help us to reveal the correlation between the mortality and EVD procedure.

Ethics Committee Approval: Health sciences university non-interventional research ethics Committee granted approval for this study (date: 28.01.2020, number: 464I89262020-32).

Peer-review: Internally peer-reviewed.

Authorship Contributions: Concept: S.Y.; Design: S.Y.; Supervision: A.K.; Materials: S.Y.; Data: S.Y.; Analysis: S.Y., A.K.; Literature search: S.Y.; Writing: S.Y.; Critical revision: A.K.

Conflict of Interest: None declared.

Financial Disclosure: The authors declared that this study has received no financial support.

\section{REFERENCES}

1. Muralidharan R. External ventricular drains: Management and complications. Surg Neurol Int 2015;6:S271-4. [CrossRef]

2. Cinibulak Z, Aschoff A, Apedjinou A, Kaminsky J, Trost HA, Krauss JK. Current practice of external ventricular drainage: a survey among neurosurgical departments in Germany. Acta Neurochir (Wien) 2016;158:847-53. [CrossRef]

3. Fried HI, Nathan BR, Rowe AS, Zabramski JM, Andaluz N, Bhimraj $A$, et al. The Insertion and Management of External Ventricular Drains: An Evidence-Based Consensus Statement: A Statement for Healthcare Professionals from the Neurocritical Care Society. Neurocrit Care 2016;24:61-81. [CrossRef]

4. Yuen J, Selbi W, Muquit S, Berei T. Complication rates of external ventricular drain insertion by surgeons of different experience. Ann R Coll Surg Engl 2018;100:221-5. [CrossRef]

5. Dey M, Jaffe J, Stadnik A, Awad IA. External ventricular drainage for intraventricular hemorrhage. Curr Neurol Neurosci Rep 2012;12:24-33.

6. Gündüz B, Ekinci B, Ucar B, Toplamaoglu H. Factors that increase the risk of infection during external ventricular catheterization. Türk Nöroşir Derg 2006;16:105-9.

7. Afif AM, Abdullah JM, Siregar JA, Idris Z. A Retrospective Study on the First Cerebrospinal Fluid Taken from External Ventricular Drainage Insertion in Meningitis Patients with Hydrocephalus. Malays J Med Sci 2019;26:64-73. [CrossRef]

8. Baysallar M, Izci Y, Kilic A, Avci IY, Senses Z, Doganci L. A case of ventricular drainage infection with a rare pathogen in cerebrospinal fluid: vancomycin-resistant Enterococcus faecium. Microb Drug Resist 2006;12:59-62. [CrossRef]

9. Champey J, Mourey C, Francony G, Pavese P, Gay E, Gergele L, et al. Strategies to reduce external ventricular drain-related infections: a multicenter retrospective study. J Neurosurg 2019;130:2034-9. [CrossRef]

10. Sam JE, Lim CL, Sharda P, Wahab NA. The organisms and factors affecting outcomes of external ventricular drainage catheter-related ventriculitis: A Penang experience. Asian J Neurosurg 2018;13:250-7. [CrossRef]

11. Song P, Duan FL, Cai Q, Wu JL, Chen XB, Wang Y, et al. Endoscopic Surgery versus External Ventricular Drainage Surgery for Severe Intraventricular Hemorrhage. Curr Med Sci 2018;38:880-7. [CrossRef]

12. Seçer HI, Düz B, Izci Y, Tehli O, Solmaz I, Gönül E. Tumors of the lateral ventricle: the factors that affected the preference of the surgical approach in 46 patiens. Turk Neurosurg 2008;18:345-55.

13. Nakashima T, Iijima K, Muraoka S, Koketsu N. Acute hydrocephalus 
requiring external ventricular drainage following perimesencephalic nonaneurysmal subarachnoid hemorrhage in a pediatric patient: Case reportand review of the literature. World Neurosurg 2019;129:283-6.

14. Hepburn-Smith M, Dynkevich I, Spektor M, Lord A, Czeisler B, Lewis A. Establishment of an External Ventricular Drain Best Practice Guideline: The Quest for a Comprehensive, Universal Standard for External Ventricular Drain Care. J Neurosci Nurs 2016;48:54-65. [CrossRef]

15. Basaldella L, Marton E, Fiorindi A, Scarpa B, Badreddine H, Longatti P. External ventricular drainage alone versus endoscopic surgery for severe intraventricular hemorrhage: a comparative retrospective analysis on outcome and shunt dependency. Neurosurg Focus 2012;32:E4. [CrossRef]

16. Izci Y, Kayali H, Daneyemez M, Koksel T, Cerrahoglu K. The clinical, radiological and surgical characteristics of supratentorial penetrating craniocerebral injuries: a retrospective clinical study. Tohoku J Exp Med 2003;201:39-46. [CrossRef]

17. Izci Y, Kayali H, Daneyemez M, Koksel T. Comparison of clinical outcomes between anteroposterior and lateral penetrating craniocerebral gunshot wounds. Emerg Med J 2005;22:409-10. [CrossRef]

18. Erdogan E, Izci Y, Gonul E, Timurkaynak E. Ventricular injury following cranial gunshot wounds: clinical study. Mil Med 2004;169:691-5.

19. Solmaz I, Kural C, Temiz C, Seçer HI, Düz B, Gönül E, et al. Traumatic brain injury due to gunshot wounds: a single institution's experience with 442 consecutive patients. Turk Neurosurg 2009;19:216-23.

20. Bhargava D, Alalade A, Ellamushi H, Yeh J, Hunter R. Mitigating effects of external ventricular drain usage in the management of severe head in- jury. Acta Neurochir (Wien) 2013; 155:2129-32. [CrossRef]

21. Chau CYC, Craven CL, Rubiano AM, Adams H, Tülü S, Czosnyka M, et al. The Evolution of the Role of External Ventricular Drainage in Traumatic Brain Injury. J Clin Med 2019;8:1422. [CrossRef]

22. Verma A, Bhani D, Tomar V, Bachhiwal R, Yadav S. Differences in Bacterial Colonization and Biofilm Formation Property of Uropathogens between the Two most Commonly used Indwelling Urinary Catheters. J Clin Diagn Res 2016;10:PC01-3. [CrossRef]

23. Izci Y, Secer H, Akay C, Gonul E. Initial experience with silver-impregnated polyurethane ventricular catheter for shunting of cerebrospinal fluid in patients with infected hydrocephalus. Neurol Res 2009;31:234-7.

24. Secer HI, Kural C, Kaplan M, Kilic A, Duz B, Gonul E, et al. Comparison of the efficacies of antibiotic-impregnated and silver-impregnated ventricular catheters on the prevention of infections. An in vitro laboratory study. Pediatr Neurosurg 2008;44:444-7. [CrossRef]

25. Lajcak M, Heidecke V, Haude KH, Rainov NG. Infection rates of external ventricular drains are reduced by the use of silver-impregnated catheters. Acta Neurochir (Wien) 2013;155:875-81. [CrossRef]

26. Lemcke J, Depner F, Meier U. The impact of silver nanoparticle-coated and antibiotic-impregnated external ventricular drainage catheters on the risk of infections: a clinical comparison of 95 patients. Acta Neurochir Suppl 2012;114:347-50. [CrossRef]

27. Nilsson A, Uvelius E, Cederberg D, Kronvall E. Silver-Coated Ventriculostomy Catheters Do Not Reduce Rates of Clinically Diagnosed Ventriculitis. World Neurosurg 2018;117:e411-6. [CrossRef]

\section{ORIJINAL ÇALIŞMA - ÖZET}

\section{Yaşlı ve intraventriküler kanaması olan hastalar eksternal ventrikül drenajı sonrası enfeksiyona daha yatkındır}

\section{Dr. Soner Yaşar, Dr. Alparslan Kırık}

Sağlık Bilimleri Üniversitesi Gülhane Eğitim ve Araştırma Hastanesi, Beyin ve Sinir Cerrahisi Kliniği, Ankara

AMAÇ: Eksternal ventrikül drenajı (EVD) nöroşirürjide hayat kurtarıcı ve acil uygulanan bir girişimdir. Ancak enfeksiyon, EVD uygulanan hastalarda temel sorundur. Bu çalışmanın amacı, EVD'li hastaların enfeksiyon oranlarını analiz etmek ve enfeksiyon ve mortalite oranlarına katkıda bulunan faktörleri belirlemektir.

GEREÇ VE YÖNTEM: 20।8-2019 yılları arasında acil EVD prosedürü uygulanan hastaların verileri geriye dönük olarak incelendi. Hastaların demografik özellikleri kaydedildi. Yaş, cinsiyet, EVD endikasyonu ve süresi ile enfeksiyon ve mortalite oranı arasındaki ilişki araştııılı.

BULGULAR: Toplam 47 hastaya iki yıllık dönemde acil EVD uygulandı. Otuz (\%63.83) hasta erkek, 17'si kadın olup ortalama yaş 28.02 idi. Ortalama drenaj süresi 6.2 gündü. Drenaj döneminde 58 beyin omurilik sIvısı (BOS) örneği analiz edildi ve 14 (\%24. I4) örnekte BOS kültürü pozitif bulundu. En yaygın mikroorganizma Staphylococcus epidermidis idi. Altı günden daha uzun süren yaşlı ve erkek hastalarda enfeksiyon oranı yüksekti. Dokuz (\%।9.15) hasta tedavi süresince öldü ve altısında intraventriküler kanama vardı.

TARTIŞMA: Altmış beş yaş üstü ve intarventriküler kanaması olan hastalarda EVD süresi daha kısa olmalıdır. Bu hasta grubunda mortalite daha yüksektir.

Anahtar sözcükler: Beyin-omurilik sıvısı; eksternal ventrikül drenaji; mortalite; nöroşirürji.

Ulus Travma Acil Cerrahi Derg 2020;26(6):870-874 doi: 10.14744/tjtes.2020.06159 